\section{Women's Access to Education in Nepal: Intergenerational Change}

Mira Mishra

\section{Abstract}

This paper describes intergenerational changes in women's access to education in Nepal. It links up the changes with changing socioeconomic processes and suggests that women's access to education is increasing by generation. And by linking up Anthony Giddens's Structuration Theory (1984) with the finding, the paper shows the interplay of both structure and agency in bringing changes in women's access to education. This paper also shows the rural urban differences in access to education and links up between marriage and education. The paper begins with the brief introduction of Nepal and Nepali women, goes on to theoretical arguments on structure and agency debate, and then describes methodology and characteristics of 39 women interviewees and discusses changes.

Keywords: women, generation, change, structure, agency

\section{Introduction}

Nepal is a tiny South Asian country which is nestled between the two hugely populated and economically growing countries (China and India) of the world. Nepal is diverse in terms of language, ethnic/caste, religion, spatial location, and class, etc. Women of Nepal who constitute more than half of the total (26494504)

\section{$50 \mid$ Mira Mishra}

population of the country (CBS, 2012) also are diverse. Therefore, it is difficult to generalize women's access to education. Prof Srinivas in The Changing Position of Indian Women has mentioned the problem of generalization of women of India in this way. Because of the existence of considerable variation among regions, between rural and urban areas, among classes and among different religion, caste/ethnic groups, generalization of women in India is difficult (Srinivas, 1978:7). Third wave feminism that emerged in US in early 1980s also identifies diversity between women. And it has pinpointed the problem of generalization.

\section{Transition in women's lives in Nepal: education}

There is considerable improvement in women's lives during the last 20 years period. Women's entry to formal schooling has relatively short history. Before 1950, education for women was virtually closed. While approximately two percent of women were literate during the 1950s, the proportion stood at 4 percent, 12 percent, 25 percent and 42.5 percent in 1971, 1981, 1991 and 2001, respectively (UNFPA 1997). CBS (2013) suggests that the literacy rate of women has gone up to $57.4 \%$. Although the overall literacy rate has increased substantially during the last ten years, gender gap persists. Regional gap in access to literacy is even more pronounced: the Kathmandu District has the highest literacy rate (86.3\%) whereas the Rautahat District has the lowest (41.7\%). Similarly, women's access to education has increased at all levels of education and the gender gap in primary and secondary education has narrowed down considerably compared to those during the 1970s and 1980s (UNDP 2002). Because of spread of literacy and education, higher level of involvement in nonagricultural pursuits, access to media and expansion of the public domain in general, the youngest generation of women is much more informed about the wider society and the public domain than was the case with the older generation. 


\section{Theoretical arguments}

Two dominant theoretical positions remained salient in explaining changes in the lives of people for a long time. Structuralist positions such as Structural Functionalism and Marxism privilege the macro level and argue that it is the macro structures that shape and reshape lives of individual human being. Theoretical positions that emphasize the micro level, e.g., Symbolic Interactionism, Phenomenology and Ethnomethodology as well as psychologically-inclined social scientists, on the other hand, tend to privilege the individual and underplay the significance of the structure, including in relation to social change. These positions argue that both self and society are continuously constructed and reshaped by means of social interaction and negotiation (Lindsey, 1997: 8). Giddens has taken a middle ground in the debate on the agency versus structure debate, including in relation to social change (Giddens, 1984). He tries to "bring individuals back into social theory” (Adams and Sydie, 2001: 384). For him, individual acts produce structure and these structures facilitate or constraint further action (Adams and Sydie, 2001: 384).

Much of the information generated for this study is of a primary nature, generated from in-depth interviews with 39 women from three different generations. Altogether 13 households were selected. In each household, three generations women consisted. The selected households, thus, are joint (or extended) and patrilineal and patrilocal in structure. The aim of the study was to see what changes had taken place among a grandmother, the mother-in-law and an unmarried granddaughter within a particular household. The primary focus of the study was on women's education. The women I talked to were selected on a purposive basis. Mode of inquiry was qualitative. I have chosen oral history interview. Oral testimony is invaluable for historians who seek information unlikely to be contained in written record (Reinharz, 1992: 131). I utilized checklist to facilitate conversation with the women interviewed. Audio tape was used to record the conversation. The following tables show spatial location and description of women interviewees. The spatial location of this

\section{2 | Mira Mishra}

research work is urban and the rural areas of Kathmandu. Further, it also includes the different caste groups, including the Dalits. Several women from the various ethnic groups have also been interviewed. It also includes various economic, income and occupational groups.

Table 1: Locations of study and interviewees across three generations

\begin{tabular}{|l|l|l|l|l|}
\hline & $\begin{array}{l}\text { Number of } \\
\text { first-generation } \\
\text { Lomen } \\
\text { (grandmother) } \\
\text { interviewees }\end{array}$ & $\begin{array}{l}\text { Number of second- } \\
\text { generation women } \\
\text { (daughter-in-law) } \\
\text { interviewees }\end{array}$ & $\begin{array}{l}\text { Number of } \\
\text { third- } \\
\text { generation } \\
\text { women } \\
\text { (granddaughter) } \\
\text { interviewees }\end{array}$ & Total \\
\hline $\begin{array}{l}\text { Urban } \\
\text { Kathmandu }\end{array}$ & 5 & 5 & 5 & 15 \\
\hline $\begin{array}{l}\text { Rural } \\
\text { Kathmandu }\end{array}$ & 8 & 8 & 8 & 24 \\
\hline Total & 13 & 13 & 13 & 39 \\
\hline
\end{tabular}

Source: Fieldwork by author in 2009

\section{Description of Interviewed Women}

The women interviewed for the study come from a variety of backgrounds. They belong to different generations and age, status within household, spatial, caste and ethnic group, marital status and educational attainment, etc. Women in first and second generations are married and have children. Women in the third generation are unmarried. And all of these young women had come of age. 
Table 2: Ethnic, caste and regional affiliation of interviewees

\begin{tabular}{|l|l|l|l|l|}
\hline Location & $\begin{array}{l}\text { High } \\
\text { Caste }\end{array}$ & Dalit & Ethnic & Total \\
\hline $\begin{array}{l}\text { Urban } \\
\text { Kathmandu }\end{array}$ & 9 & NA & 6 & 15 \\
\hline $\begin{array}{l}\text { Rural } \\
\text { Kathmandu }\end{array}$ & 15 & 9 & NA & 24 \\
\hline Total & 24 & 9 & 6 & 39 \\
\hline
\end{tabular}

Source: Fieldwork by author in 2009

All in all, among the 39 women, there are 24 "high caste" women from the Hills. Of these women, nine are from urban Kathmandu and 15 from rural Kathmandu. Out of 24 "high caste" women, 15 were Brahmin and remaining nine were Chhetri. Nine women were Hill Dalits from rural Kathmandu. There are six Newar women from Urban Kathmandu. The women are distributed along a wide range of educational attainment. Some are illiterate, most have completed school and many others are college students or have graduated from college.

\section{Educational Attainment by Generation}

A majority of women in the first generation was illiterate. Only a very few possessed literacy skills. Not a single woman had attended a school. Majority of women from second generation was also illiterate. A few had gone to school. A very few had higher education. All women except one in the third generation had gone to school. A majority of women in the third generation is still continuing their education. A few had attained higher education as well. Table 3 shows their educational attainment.

\section{4 | Mira Mishra}

Table 3: Educational attainment across three generations

\begin{tabular}{|c|c|c|c|c|}
\hline Location & $\begin{array}{l}\text { Household } \\
\text { Number }\end{array}$ & $\begin{array}{l}\text { First } \\
\text { generation } \\
\text { (Grandmo } \\
\text { ther) }\end{array}$ & $\begin{array}{l}\text { Second } \\
\text { generation } \\
\text { (Daughter- } \\
\text { in-law) }\end{array}$ & $\begin{array}{l}\text { Third generation* } \\
\text { (Granddaughter) }\end{array}$ \\
\hline \multirow[t]{5}{*}{ Kathmandu } & 1 & Literate & $\begin{array}{l}14 \quad \text { years } \\
\text { completed }\end{array}$ & 15 years completed \\
\hline & 2 & Literate & $\begin{array}{l}10 \quad \text { years } \\
\text { completed }\end{array}$ & 10 years completed \\
\hline & 3 & Literate & $\begin{array}{l}16 \quad \text { years } \\
\text { completed }\end{array}$ & 14years completed \\
\hline & 4 & Literate & $\begin{array}{l}16 \quad \text { years } \\
\text { completed }\end{array}$ & 14 years completed \\
\hline & 5 & Literate & $\begin{array}{l}10 \quad \text { years } \\
\text { completed }\end{array}$ & 15 years completed \\
\hline \multirow{8}{*}{$\begin{array}{l}\text { Rural } \\
\text { Kathmandu }\end{array}$} & 6 & Illiterate & Illiterate & 11 years completed \\
\hline & 7 & Illiterate & Illiterate & 10 years completed \\
\hline & 8 & Illiterate & $\begin{array}{l}1 \text { year } \\
\text { competed }\end{array}$ & 10 years completed \\
\hline & 9 & Illiterate & $\begin{array}{l}9 \quad \text { years } \\
\text { completed }\end{array}$ & 8 years completed \\
\hline & 10 & Illiterate & Illiterate & 8 years completed \\
\hline & 11 & Illiterate & Illiterate & 11 years completed \\
\hline & 12 & Illiterate & $\begin{array}{lr}2 & \text { years } \\
\text { completed }\end{array}$ & 5 years completed \\
\hline & 13 & Illiterate & Illiterate & 11 years completed \\
\hline
\end{tabular}

Source: Field work by author in 2009

* For majority in the third-generation women, schooling is continuing

In first generation, those women who were literate were from Kathmandu. One woman, who was born in 1945, had an 


\section{6 | Mira Mishra}

opportunity to go to school. But her grandfather refused to send her there. Women in the first generation were born at a time when Nepal was virtually closed to the outside world. They were also excluded from access to schooling. The country was under Rana oligarchy. Norms and laws of the state were shaped by the first written legal code of 1854, which was itself influenced by the ancient philosophy enunciated in the Manusmriti, an ancient Hindu religious and socio-political text. The text, among others, called for child marriage, especially for girls, in order to ensure caste purity. Women were not at all conceptualized as independent and informed persons. They were envisioned largely as dependent daughters who ought to be guarded by the father or older brother before her marriage and by her husband after marriage. There was no possibility of the growth of individuality of women at that period.

Women in the second generation, who were born between the late 1960s and the early 1970s, were also, to a large extent, denied access to education. However, there was much sharp rural-urban difference on this front. A majority of women, including those in the rural areas were illiterate. All second generation urban women, on the other hand, were schooled and literate. The urban women, in consequence, were married off at a relatively late age. All five women respondents from Kathmandu had completed 10 years of schooling. Two of them had completed the Master's level and one was a college graduate. Their ages at marriage ranged from 18 to 27 years. Their marriage also took place after they had passed 18 years of age. It should be noted that women's age at marriage, their educational attainment and their engagement at paid work are highly correlated. Out of five respondents from urban Kathmandu, four were employed in various educational sectors. One had a family business. Interestingly, three of them, who had completed the graduate level, were employed prior to their marriage. Two entered into paid work after marriage.

The new civil code introduced in 1963 sought to eradicate child marriage, polygyny and extreme age hypergamy. The 1960s was also a decade when girls started enrolling in schools. A majority of the second-generation women, however, did not attend school. It was not that there was no school close to their village. Their brothers and husbands had attended schools and had acquired some years of schooling. Some of the women also had a few years' of schooling. But households, rural households in particular, did not prioritize girl's education. Nor did the girls themselves strongly insist that they, like their brothers, be sent to school. Instead, many women were also happy fetching water and collecting fodder with friends because almost all the women did the same.

Gender bias in education is reflected on a narrative of a 65 years old Kanchhi from the rural areas of Kathmandu. Kanchhi notes,

I did not go to school because at that time there was no school in this village. Nobody went to school. However, there was a school started nearby when I had already given birth to children. We sent our sons to school but we did not send our daughters there. We wanted the daughters to get married soon instead. There was no tradition in our village of sending a daughter to school. There was actually no meaning in sending a daughter to school. Because they were not paying us back in our old days as our sons do. But our granddaughter did attend the school. She is now in Grade 11. Time has changed. Everybody goes to school. Nobody stays at home.

And then she laughs. Her son, 44, added that there was not a single girl in his class at that time. Even boys did not attend school for the full duration. He himself wanted to be at school for a long period but ended up only with four years of schooling because he had to work in the family farm. A majority of the second-generation women had a similar experience. A few did wish to go to school themselves. But, and often, because of economic, social and cultural reasons, these women did not continue in school for long.

The interplay of structure and agency, as Giddens had argued, in The Constitution of Society (1984), can clearly be discerned in the lives of women I spoke to. Women of the first generation did not go to school because there was no structure, i.e. no provisioning of 
education for girls. As such, they did not perform out up an agency performance regarding schooling, e.g. by insisting to their parents that that they be sent to a school. But for women in the second generation, there were schools available, schooling was valued and their brothers were attending the local schools. Still, most did not insist that they be admitted to a school. Instead, most regularly reminded themselves of their role as a daughter and helped their mothers in domesticity and sibling care. There were very few women attending school in the rural areas in any case. Women in the third generation have increasingly greater access to schooling. They insisted that they should be admitted to a school and be kept there for longer. With the longer schooling, they were also refusing early marriage.

Education and marriage: There is also a strong correlation between age at marriage and the educational attainment of women. Women in the first generation were married quite early. A few of them were married before they reached 10 years of age. A majority was not able to read and write. A very few were literate. But no one had the experience of formal schooling. Those who were literate were from urban Kathmandu.

A majority of second-generation women was also married off at an early age. And they were also largely denied the access to education. However, there was a sharp rural-urban difference in access to education. An overwhelming majority of second generation women from rural areas were illiterate whereas women from the urban Kathmandu had a much longer schooling. Therefore, the latter category of women was married off at a relatively late age. All five women respondents from Kathmandu had completed 10 years of schooling. Two of them had completed the Master's level and one had completed the Bachelor's level. Their age at marriage also ranged from 18-27 years. The third generation women intend to marry late. A majority of them has already acquired 10 years of schooling. An overwhelming majority of third generation is in school and intends to be there for some more years. Several other studies also suggest that the lower the educational attainment of women, the higher the chance of

\section{8| Mira Mishra}

marriage at early years (Choe et al., 2005). Women's age at marriage, their educational attainment and their engagement at paid work are highly correlated.

Table 4: Age at marriage and educational attainment by generation

\begin{tabular}{|l|l|l|l|l|l|l|}
\hline Name & Generation & Age & $\begin{array}{l}\text { Social } \\
\text { category }\end{array}$ & Education & $\begin{array}{l}\text { First } \\
\text { mens } \\
\text { es }\end{array}$ & $\begin{array}{l}\text { Age at } \\
\text { marriage }\end{array}$ \\
\hline Sushila & Grandmother & 66 & $\begin{array}{l}\text { Newar } \\
\text { Buddhist }\end{array}$ & Literate & 15 & 14 \\
\hline Sita & $\begin{array}{l}\text { Daughter-in- } \\
\text { law }\end{array}$ & 43 & $\begin{array}{l}\text { Newar } \\
\text { Buddhist }\end{array}$ & $\begin{array}{l}10 \text { years } \\
\text { completed }\end{array}$ & 14 & 18 \\
\hline Soni & Granddaughter & 24 & $\begin{array}{l}\text { Newar } \\
\text { Buddhist }\end{array}$ & $\begin{array}{l}15 \text { years } \\
\text { completed }\end{array}$ & 13 & $\begin{array}{l}\text { Want to } \\
\text { marry } \\
\text { after 25 }\end{array}$ \\
\hline
\end{tabular}

Source: Fieldwork by author in 2009

A case of a business family of Kathmandu reflects the change in the age at marriage and women's capacity to play the agency role. Sushila, 66, the grandmother, was married at 14 , one year prior to her menstruation. She did not attend schools because of two main reasons. First, there were very few women in Kathmandu who went to school at that time. Second, her grandfather, who had absolute authority over household decisions, did not want her to attend a school. He, instead, wanted to marry her off before her menstruation. Sita, 43, the daughter -in-law, was married at 18, four years after her menstruation. She had just completed her school levels (SLC) and had started going to a college. She was then married. Her marriage was fixed two years earlier, when she was 16 . She could not continue her study after marriage as she belonged to a business family who had to run their family shop. And she had to work both at managing the home and running the shop. Soni, 24, the granddaughter, is currently studying her MBA. She intends to marry only after the completion of this degree. In the mean time, she is employed at a bank as an intern. Her 
grandmother worries that Soni's marriage is getting delayed. Her mother, however, thinks that a woman should complete her education before her marriage. Marriage could otherwise restrict women from getting adequate education due to the pressure of household duties and bearing and rearing of children. Soni herself thinks that a woman should complete her higher education and find a job before her marriage. She sometimes has doubts about stability in marriage. She thinks that in case a woman has to face hardship in marriage, the woman has to be able to stand on her own by "managing our lives by ourselves." The overall pattern indicates that demographic transition that is underway is likely to become more pronounced in future. It would be more so in the urban areas earlier on.

\section{Conclusion}

To conclude, gender gap in education in Nepal is narrowing. As compared to mothers and grandmothers, young women in contemporary Nepal have greater access to all levels of education. It is particularly true for young women in urban areas. Age, spatial location and government policies as structures have greater role among others in ensuring women's access to schooling. In addition, women's agency also plays a vital role.

\section{References}

Adams, Bert and R.A. Sydie. (2001). Sociological Theory. New Delhi: Vistaar.

CBS (2012). National Population and Housing Census 2011 (National Report) Kathmandu: CBS.

Choe, Minja Kim, Shyam Thapa and Vinod Mishra. (2005). 'Early marriage and early motherhood'. Journal of Bio-social Science. 37: 143-162.

Giddens, Anthony. (1984). The Constitution of Society: Berkeley: University of California Press.

\section{$60 \mid$ Mira Mishra}

Lindsey, Linda L. (1997). Gender Roles: A Sociological Perspective. New Jersey: Prentice-Hall.

Reinharz, Shulamit.(1992). Feminist Methods in Social Research .New York: Oxford University Press.

Srinivas, M.N. (1978). The Changing Position of Indian Women. Bombay: Oxford University Press.

UNDP (United Nations Development Program). (2002). Nepal: Millenium Development Goals Progress Report. Kathmandu: UNDP.

UNFPA (United Nations Fund for Population Activities). (2007). Gender Equality and Empowerment of Women in Nepal. Nepal: UNFPA. 